33. De Sousa N.R., Loureiro Luna S.P., Pizzigatti D., Martins M.T.A., Possebon F.S.,Aguiar A.C.S. Relation between type and local of orthopedic injuries with physical activity in horses. Ciência Rural. 2017. V. 47. № 2. URL: http://www.scielo.br/scielo. php? script $=$ sci arttext\&pid $=$.

34. Slater J. National Equine Health Survey (NEHS). Blue Cross. 2018. URL: https:// www.bluecross.org.uk/ sites/default/files/downloads/NEHS-results-2018.pdf.

UDC 619: 616.995.1-036/.08: 636.4

DOI https://doi.org/10.32851/2226-0099.2020.115.32

\title{
COMPARISON OF TREATMENT AND ECONOMIC EFFICACY OF ANTIHELMINTHICS FOR SWINE ASCARIASIS
}

\author{
Soloviova L.M. - Candidate of Veterinary Sciences, Associate Professor, \\ Associate Professor of Parasitology and Pharmacology Department, \\ Bila Tserkva National Agrarian University \\ Yerokhina O.M. - Lecturer at the Department of Veterinary Medicine, \\ Technological and Economic Professional College of the Bila Tserkva \\ National Agrarian University \\ Peresunko O.D. - Lecturer at the Department of Veterinary Medicine, \\ Technological and Economic Professional College of the Bila Tserkva \\ National Agrarian University \\ Chovgun A.M. - Lecturer at the Department of Veterinary Medicine, \\ Technological and Economic Professional College of the Bila Tserkva \\ National Agrarian University
}

It was found that the causative agent of ascariasis is the most common among nematodes of pigs of different ages and production groups. Of the 150 helminthocoprooscopically examined samples, ascarides affected 74 heads, i.e. the extent of invasion (EI) was $49.3 \%$ with the intensity of invasion (II) of 24.4 specimens of eggs.

We tracked the infestation of pigs in each age group and found that firstly we found ascaris eggs in pigs aged from 1.5 to 2 months. Extensity and intensity of infestation was respectively $13.3 \%$ and 5.5 specimens of eggs. Then extensity and intensity of infestation dramatically increased. Thus, in pigs aged 2-4 months, respectively, it accounted for $64.6 \%$ and 22.5 specimens of the eggs, so they were the most affected. The pigs aged 4-6 months also had a high degree of damage by ascarides. Extensity of invasion was $78.4 \%$ with intensity of infestation 31.9 specimens of eggs. Then extensity and intensity of ascaris infestation significantly decreased, and in fattening pigs it was, respectively, $37.1 \%$ and 12.5 egg specimens; in sows it was $16.7 \%$ and 3.5 specimens of eggs, respectively.

The intensity of ascaris infestation ranged in groups from 20.3 to 30.8 eggs.

On the 12th day after the last intake of anthelmintics, we sampled the faeces again.

The results of helminthological tests after deworming indicate that $1 \%$ brovalsen and promectin provided a 100\% therapeutic effect for pig ascaris invasion. Animals in the control group were infected with pathogens of ascariasis $(E I=100 \%, I I=27.8$ eggs $)$.

In order to study the effect of ascarides on the body of pigs, at the beginning of the experiment and after 30 days the animals were weighed, as the assessment of the effectiveness of the tested drug was carried out also in terms of average daily gain.

During the period of the experiment, which lasted 30 days, the average weight of pigs from research groups as the first as well as the second was higher than in the control group: the first experimental group by $1.98 \mathrm{~kg}$ or by $28.2 \%$, and the second - by $2.27 \mathrm{~kg}$ or by $32,3 \%$.

Key words: helminthiasis, anthelmintics, ascariasis, pigs, promectin, brovalsen. 
Соловйова Л.М., Срохіна О.М., Пересунько О.Д., Човгун А.М. Порівняння лікувальної та економічної ефективності антигельмінтиків за аскарозу свиней

Встановлено, що найчастіше серед нематодозів свиней різних вікових та виробничих груп зустрічається збудник аскарозу.

Із 150 досліджених нами гельмінтокопроовоскопічно проб аскарисами було уражено 74 голови, тобто екстенсивність інвазї (ЕI) становила 49,3\% при інтенсивності інвазіі (II) 24,4 екземпляра яєиь.

Ми простежили за ураженістю свиней по кожній віковій групі і встановили, що вперше яйця аскарисів ми знайшли у поросят у віщі від 1,5 до 2 місящів. Екстенсивність та інтенсивність інвазії становила, відповідно, 13,3\% і 5,5 екземпляра яєиь. Потім екстенсивність та інтенсивність інвазії різко наростала. Так, у поросят віком 2-4 місяиі, відповідно, становила 64,6\% та 22,5 екземпляра яєць, отже, вони були максимально уражені. Свині віком 4-6 місяців також мали високу ступінь ураження аскарисами. Екстенсивність інвазії становила 78,4\% при інтенсивності інвазії 31,9 екземпляра яєць. Потім екстенсивність та інтенсивність аскарозної інвазії значно зменшувалися і у свиней, які знаходилися на відгодівлі, становили, відповідно, 37,1\% та 12,5 екземпляра яєиь, а у свиноматок вони становили 16,7\% і 3,5 екземпляра яєць відповідно.

Інтенсивність аскарозної інвазії коливалася у групах від 20,3 до 30,8 екз. яєцьь.

На 12-й день, після останньої дачі антигельмінтних препаратів, ми знову відібрали проби фекалій.

Результати гельмінтокопроовоскопічних досліджень свиней після дегельмінтизаиії свідчать про те, щяо бровальзен та промектин 1\% забезпечили 100\%-ний лікувальний ефект свиней від аскарозної інвазії. Тварини контрольної групи були вражені збудниками аскарозу $(E I=100 \%, I I=27,8$ екз. яєць).

3 метою вивчення впливу аскарисів на організм свиней на початку проведення досліду i через 30 днів були проведені зважування тварин, оскільки оиінку ефективності випробуваного препарату здійснювали ще $і$ за рівнем середньодобових приростів.

За період досліду, який тривав 30 днів, середня маса поросят дослідних груп, як першої, так і другої, була більшою, ніж у контрольної групи: в першій дослідній групі на 1,98 кг, або на 28,2\%, а у другій - на 2,27 кг, або на 32,3\%.

Ключові слова: гельмінтози, антигельмінтики, аскароз, свині, промектин, бровальзен.

Formulation of the problem. Intestinal nematodes of pigs cause significant economic losses, which consist of reduced productivity of pigs, reduced product quality, loss of breeding value of animals [1, p. 10; 2, p. 19; 3, p. 1906]. According to the literature, the daily increase in young pigs at rearing and fattening under the influence of parasitic infestation is reduced by $20-60 \%$. At the same time, feed costs for weight gain increase (from 25 to $100 \%$ ), as the fattening period is extended by 2,0-2,5 months $[4$, p. $23 ; 5$, p. 44$]$.

Ascarosis of pigs is common in all regions of Ukraine. Infection with roundworms occurs in piggeries in the case of feeding infested feed and water. Piglets are affected during licking of the sow's nipples. Lack of vitamins A and D in the feed, as well as insufficient mineral feeding increase the degree of infection, because the animals eat the land infested with eggs, and earthworms are a reservoir of ascaris larvae [6, p. 23; 7, p. 20].

Deworming, which is considered not only as a therapy but also as a prevention of helminthiasis, occupies a prominent place in the complex of special measures. Therefore, the development of effective schemes of etiotropic therapy of pigs infected with roundworms, using new antiparasitic drugs with a broad spectrum of action, is relevant for practice.

Analysis of the recent researches and publications. The effect of nematodes on the body of pigs is accompanied by secondary hypovitaminosis. Helminths affect the functional activity of the immune system, reducing the natural reactivity of the infected organism. Allergic syndrome also occurs [7, p. 20; 8, p. 25; 9, p. 62; 10, p. 133].

The question of whether helminths A. suum and A. lumbricoides are one species is also currently unresolved. However, according to Daniela Leles, Scott L. Gardner et al. 
[8, p. 25], the eggs of pathogens found in fecal material are morphologically identical, but mature pathogens have slight differences.

At slaughterhouses you can find mature helminths in the intestines, as well as liver damage ("white dots") and lungs. The signs of pneumonia or pleurisy can be indicators of ascariasis [3, p. 1908], and the study of nasal and pulmonary secretions in piglets can detect the presence of ascaris larvae [7, p. 20].

According to A. R. Szakacs, V. Miclăuş et al. [11], interstitial tissue and bronchioles were affected in the lungs. Zonal necrosis was observed on the epithelium of the bronchioles, with detachment of cells into the lumen of the bronchioles, the intensity of which differed depending on one part of the lung parenchyma to another.

According to the literature, the effectiveness of fenbendazole drugs, such as phenzol at a dose of $5 \mathrm{mg} / \mathrm{kg}$ on DR for ascarosis of pigs, EE of which was $90 \%$, and IE $=99 \%$

Table 1

The results of helminthocoprooscopic studies for ascariasis

\begin{tabular}{|l|c|c|c|c|c|}
\hline $\begin{array}{c}\text { Age and } \\
\text { production } \\
\text { groups animals }\end{array}$ & $\begin{array}{c}\text { Total } \\
\text { studied } \\
\text { animals, ch. }\end{array}$ & $\begin{array}{c}\text { Total affected } \\
\text { animals, } \\
\text { naked. }\end{array}$ & $\begin{array}{c}\text { EI, } \\
\text { in percent. }\end{array}$ & $\begin{array}{c}\text { Total found } \\
\text { eggs, copies. }\end{array}$ & $\begin{array}{c}\text { II, } \\
\text { copy } \\
\text { eggs }\end{array}$ \\
\hline 1,5-2-monthly & 15 & 2 & 13,3 & 11 & 5,5 \\
\hline 2-4-monthly & 48 & 31 & 64,6 & 697 & 22,5 \\
\hline 4-6-monthly & 37 & 29 & 78,4 & 925 & 31,9 \\
\hline Fattening & 35 & 13 & 37,1 & 163 & 12,5 \\
\hline Sows & 12 & 2 & 16,7 & 7 & 3,5 \\
\hline Breeding boars & 3 & 0 & 0 & 0 & 0 \\
\hline Total & 150 & 74 & 49,3 & 1803 & 24,4 \\
\hline
\end{tabular}

Table 2

The results of helminthocoprooscopic studies of pigs before deworming

\begin{tabular}{|l|c|c|c|c|c|}
\hline \multicolumn{1}{|c|}{$\begin{array}{c}\text { Group } \\
\text { animals }\end{array}$} & $\begin{array}{c}\text { Number } \\
\text { animals in } \\
\text { the group, ch. }\end{array}$ & $\begin{array}{c}\text { Number } \\
\text { affected } \\
\text { animals, ch. }\end{array}$ & $\begin{array}{c}\text { EI, } \\
\text { in percent }\end{array}$ & $\begin{array}{c}\text { II., } \\
\text { copy eggs }\end{array}$ & $\mathbf{p}<$ \\
\hline $\begin{array}{l}\text { Experimental: } \\
\text { the first }\end{array}$ & 0 & 10 & 100 & $30,8 \pm 3,9$ & 0,1 \\
\hline second & 10 & 10 & 100 & $20,3 \pm 2,8$ & 0,1 \\
\hline Control & 10 & 10 & 100 & $24,8 \pm 3,5$ & - \\
\hline
\end{tabular}

Notes: EI - extent of invasion, II - intensity of invasion; $p<-$ compared experimental groups with the control.

Table 3

The results of helminthocoprooscopic studies of pigs after deworming

\begin{tabular}{|l|c|c|c|c|c|c|}
\hline \multicolumn{1}{|c|}{$\begin{array}{c}\text { Group } \\
\text { animals }\end{array}$} & $\begin{array}{c}\text { Number } \\
\text { animals in } \\
\text { the group, ch. }\end{array}$ & $\begin{array}{c}\text { Number } \\
\text { affected } \\
\text { animals, ch. }\end{array}$ & $\begin{array}{c}\text { EI, } \\
\text { in per- } \\
\text { cent }\end{array}$ & $\begin{array}{c}\text { II., } \\
\text { copy } \\
\text { eggs }\end{array}$ & $\begin{array}{c}\text { EE, } \\
\text { in } \\
\text { percent }\end{array}$ & $\begin{array}{c}\text { IE, } \\
\text { in } \\
\text { percent }\end{array}$ \\
\hline $\begin{array}{l}\text { Experimental: } \\
\text { the first }\end{array}$ & 10 & 0 & 0 & 0 & 100 & 100 \\
\hline second & 10 & 0 & 0 & 0 & 100 & 100 \\
\hline Control & 10 & 10 & 100 & $27,8 \pm 2,1$ & - & - \\
\hline
\end{tabular}


has been repeatedly confirmed [10, p. 132]. Ascarosis in piglets of 2-4 months of age was found to be $100 \%$ effective with ivomec and $64,28 \%$ with piperazine [12, p. 45].

A. suum eggs are quite stable in the environment, can remain viable in the soil from 6 to 9 years [13, p. 150], and in water at a temperature of $70-80^{\circ} \mathrm{C}$ they die within $2 \mathrm{~s}[14, \mathrm{p} .28]$.

The purpose and objectives of the study. The aim was to study the prevalence of helminthic infestation in pigs LLC "Kozatske" Bobrovytsia district of Chernihiv region and the anthelmintic properties of brovalzen and promectin 1\% in ascarosis of pigs.

To achieve this goal, the following tasks were set: to study the spread of pig ascarosis in LLC "Kozatske" Bobrovytsia district of Chernihiv region; to determine the age dynamics of pig infestation with roundworms in the farm; to study the effectiveness of deworming of pigs with brovalzen and promectin $1 \%$ for ascarosis.

Material and methods of research. Experiments to study the anthelmintic efficacy of brovalsen and promectin $1 \%$ were performed on piglets 2-4 months of age spontaneously infested with roundworms. For this purpose, on the principle of analogues formed 3 groups of pigs (1 control and 2 experimental) with 10 heads in each. Animals of the first experimental group were administered brovalzen with food at a dose of $2 \mathrm{~g} / 10 \mathrm{~kg}$ of body weight, mixing the drug with a two-day norm of feed, twice, repeating the treatment after $24 \mathrm{~h}$, in a group method. $1 \mathrm{~g}$ of brovalzen powder contains $75 \mathrm{mg}$ of albendazole (active substance). Animals of the second experimental group used promectin 1\% subcutaneously, from the inner surface of the thigh at a dose of $1 \mathrm{ml}$ per $33 \mathrm{~kg}$ of body weight once. $1 \mathrm{ml}$ of the drug contains $10 \mathrm{mg}$ of ivermectin and auxiliary components. Pigs in the control group were not prescribed anthelmintics. Anthelmintic efficacy was determined on the 12th day after deworming. Faecal samples taken individually were examined by a combined method standardized by G.O. Kotelnikov and V.M. Hrenov.

Tests to determine the effectiveness of treatment were extensibility (EE) and intensification (IE). Based on the results of weighing the animals, which was carried out before the use of drugs, as well as 30 days after their use, the average daily gain of piglets was calculated.

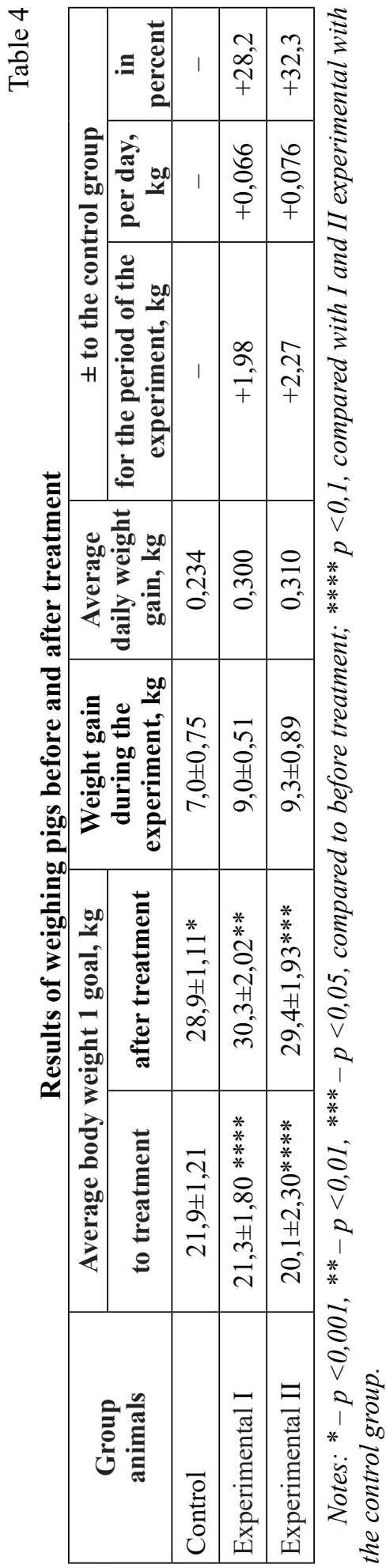


Main results of the study. In order to study the epizootic situation with helminthiasis of pigs in the farm conducted the selection and study of 150 samples of feces from pigs of different ages and production groups.

Ascaris affected 74 piglets, ie the extent of invasion (EI) was 49,3\% with an intensity (II) of 24,4 specimens of eggs (table 1).

We monitored the incidence of pigs of each age group and for the first time ascaris eggs were diagnosed in piglets aged 1,5 to 2 months. Extensiveness and intensity of invasion were, respectively, $13,3 \%$ and 5,5 specimens of eggs. Then the extent and intensity of the invasion increased sharply and in piglets aged 2-4 months, respectively, were $64,6 \%$ and 22,5 specimens of eggs. Pigs aged $4-6$ months also had a high degree of roundworm infestation. The extent of the invasion was $78,4 \%$, the intensity 31,9 specimens of eggs. Then $\mathrm{EE}$ and IE of ascariasis invasion decreased significantly and in pigs that were fattening, were, respectively, $37,1 \%$ and 12,5 specimens of eggs, and in sows $-16,7 \%$ and 3,5 specimens of eggs (table 1 ).

In groups to study the therapeutic efficacy of anthelmintics, the intensity of ascariasis invaded from 20,3 to 30,8 copies. eggs (table 2).

On the 12th day after the last administration of anthelmintic drugs, faecal samples were taken again. The results of helminthocoprooscopic studies of pigs after deworming are shown in table 3.

The results of helminthocoprovooscopic studies of pigs after deworming indicate that brovalzen and $1 \%$ promectin provided a $100 \%$ therapeutic effect in ascariasis. Animals of the control group remained affected by ascariasis pathogens $(E I=100 \%$, $\mathrm{II}=27,8$ specimens of eggs).

In order to study the effect of roundworms on pigs at the beginning of the experiment and after 30 days, the animals were weighed, as the evaluation of the effectiveness of the test drug was carried out at the level of average daily gain (table 4).

Table 4 shows that during the experiment, which lasted 30 days, the average body weight of piglets in the experimental groups of both the first and second was higher than in the control group: in the first - by $1,98 \mathrm{~kg}(28,2 \%)$, the second - 2,27 $\mathrm{kg}(32,3 \%)$.

Conclusions. 1. Ascariasis invasion has a well-defined age dynamics. 2. Brovalzen at a dose of $2 \mathrm{~g} / 10 \mathrm{~kg}$, which was administered for two days with compound feed, with a repeated course after $24 \mathrm{~h}$ and promectin $1 \%$ at a dose of $1 \mathrm{ml}$ per $33 \mathrm{~kg}$ of body weight were once effective anthelmintics for ascariasis in pigs $(\mathrm{EE}=100 \%, \mathrm{IE}=100 \%)$.

Prospects for further research. Measures to control swine ascariasis will include studying the effectiveness of new anthelmintics on this invasion and disease prevention.

\section{REFERENCES:}

1. Стибель В.В. Гельмінтози свиней : навчальний посібник. Львів : Сполом, 2004. $160 \mathrm{c}$.

2. Фещенко Д.В. Особливості епізоотології, патогенезу та терапії змішаної немато-дозної інвазії свиней. Ветеринарна медицина України. 2008. № 4. С. 18-20.

3. Advances in the diagnosis of Ascaris suum infections in pigs and their possible applications in humans / Jonny Vlaminsk, Bruno Levecke, Jozef Vercruysse, Peter Geldhof. Parasitology. 2014. № 141. P. 1904-1911.

4. Галат В.Ф., Галат М.В., Євстаф'єва В.О. Розповсюдження асоціативних інвазій свиней в умовах лісостепової та степової зон України. Вісник Полтавської держ. аграр. академї. Полтава, 2007. № 3. С. 22-24.

5. Березовський А.А. Основні паразитози свиней, особливості хіміотерапії та профілактики. Ветеринарна медицина : міжвід. темат. наук. збірник. Харків, 2006. № 86. C. 40-48. 
6. Sangster N.C., Dobson R.J. In: Lee DL (Ed) The biology of nematodes. 2001. P. 20-25.

7. Поживіл А., Горжеєв В. Концепція боротьби з гельмінтозами тварин. Ветеринарна медицина України. 2002. № 4. С. 20.

8. Are Ascaris lumbricoides and Ascaris suum a single species? / Daniela Leles, Scott L. Gardner, Karl Reinhard, Alena Iñiguez. Parasites \& Vectors. 2012. № 5.

9. Yllka Cani, Bejo Bizhga. Ascariasis in pigs, diagnose and alternative. Albanian j. agric. sci. 2017.

10. Зуев Д.В. Определение терапевтической дозы фензола при аскариозе свиней. Теория и практика борьбы с паразитарными болезнями : матеріали докл. науч. конф. Москва, 2005. Вып. 6. С. 132-134.

11. Chronic pulmonary lesions in the experimental infestation with Ascaris suum in domestic pig / A.R. Szakacs, V. Miclăuş, A. Gal, V. Rus. Annals of RSCB. 2013. Vol. XVIII.

12. Сафиуллин Р.Т. Лечебная и экономическая эффективность премикса с ивермектином при паразитарных болезнях свиней. Ветеринария. 1995. № 6. С. 43-47.

13. Assessing the zoonotic potential of Ascaris suum and Trichuris suis: looking to the future from an analysis of the past. / P. Nejsum, M. Betson, R.P. Bendall, S.M. Thamsborg. Journal of Helminthology. 2012. № 86. P. 148-155.

14. Долбин Д.А., Хайруллин Р.З. Устойчивость яиц гельминтов к неблагоприятным физическим, химическим и биологическим факторам окружающей среды. Российский паразитологический журнал. 2017. Т. 39, Вып. 1.

УДК 006.032:574:631.11:664.1

DOI https://doi.org/10.32851/2226-0099.2020.115.33

\section{АНАЛІЗ НЕБЕЗПЕЧНИХ ФАКТОРІВ ТА РИЗИКІВ У ПРОЦЕСІ ВИГОТОВЛЕННЯ ВИРОБІВ ІЗ М'ЯСА ПТИЦІ}

\footnotetext{
Стріха Л.О. - к.с.-е.н., доцент кафедри технології переробки, стандартизації і сертифрікації продукції тваринництва, Миколаївський національний аграрний університет

Петрова O.І. - к.с.-г.н., доцент кафредри технології переробки, стандартизації і сертифрікації продукції тваринництва, Миколаївський національний аграрний університет

Єфіменко А.С. - магістрант кафредри технології переробки, стандартизації і сертифрікації продукції тваринництва, Миколаївський національний аграрний університет
}

Проаналізовано низку наукових досліджень і встановлено, що реформування традииійної системи управління безпечністю харчових продуктів є нагальною проблемою і в Україні. Наявні підходи не можуть вважатись доволі ефективними, оскільки вони не завжди визначають і адекватно не вирімують проблеми, не можуть забезпечити ефективне реагування на швидкий розвиток і зміни, що зумовлюють ймовірні ризики, не завжди враховують під час прийняття рімень наукові дані.

Дослідження впливу небезпечних факторів у прочесі виробничтва харчових продуктів із м'яса птииі проведено з описом характеристик продукиї, проиесів, визначення механізму дії небезпечних факторів та їх критичних меж.

Аналіз впливу небезпечних факторів на сировину (охолоджені курячі тушки) показав, що є різні джерела забруднення: недостатня концентрація миючих та дезинфікуючих речовин, недостатне відмивання, надмірна доза посолочних компонентів, розвиток фонової мікрофлори в разі порушень температурних режимів та тривалості технологічних операиій. 